\title{
Health service for diabetic foot ulcer patients during covid-19 pandemic
}

\author{
Hermawati Hermawati', Yulius Tiranda ${ }^{2}$, Sukron Sukron²
}

1 Program Studi Ilmu Keperawatan, Fakultas Ilmu Kesehatan, Institut Ilmu Kesehatan dan Tekonologi Muhammadiyah Palembang, Indonesia

2 Departemen Keperawatan Medikal Bedah, Fakultas Ilmu Kesehatan, Institut Ilmu Kesehatan dan Teknologi Muhammadiyah Palembang, Indonesia

\begin{tabular}{|c|c|}
\hline Article Info & Abstract \\
\hline $\begin{array}{l}\text { Article History: } \\
\text { Submitted: July } 15^{\text {th }}, 2021 \\
\text { Accepted: Nov } 10^{\text {th }}, 2021 \\
\text { Published: Nov } 25^{\text {th }}, 2021 \\
\text { Keywords: } \\
\text { health service; diabetic foot } \\
\text { ulcer; covid-19 }\end{array}$ & $\begin{array}{l}\text { In early } 2020 \text {, the whole world was shocked by the COVID-19 pandemic, } \\
\text { which impacted all aspects of life. One was changes in the service system and } \\
\text { health care for patients with diabetic foot ulcers (DFU). Wound care in DFU } \\
\text { patients should be routine but while minimizing hospital visits to reduce the } \\
\text { risk of exposure to COVID-19. The objective of this study was to explore the } \\
\text { health services provided to DFU patients during the COVID-19 pandemic at } \\
\text { the hospital. This study used a literature review approach with six electronic } \\
\text { databases, namely National Library, PubMed, Science Direct, ProQuest, } \\
\text { Springer Nature, and Wiley, in 2019-2021. The keyword used were health } \\
\text { service, diabetic foot ulcer and COVID-19. around } 669 \text { articles identified, } 12 \\
\text { articles met the inclusion. The articles reviewed were obtained from the } \\
\text { result of discussion and validations between researcher and supervisors } \\
\text { following the Prisma Guideline. Health services for DFU patients during the } \\
\text { COVID-19 pandemic may be conducted through several stages including a) } \\
\text { online consultation or telemedicine as the first stage, b) continued with } \\
\text { triage process, and c) screening for individual patients needs. Health } \\
\text { services for DFU patients during the COVID-19 pandemic have changed } \\
\text { according to the following conditions. The first procedure was to conduct an } \\
\text { online consultation (telemedicine) to assess the client's condition related to } \\
\text { complaints, then proceed with the triage process to prioritize care and } \\
\text { service needs. The health of each patient and screening to check for } \\
\text { symptoms of COVID-19 as well as carried out additional screening, CT } \\
\text { Thorax and Swab if the patient had to go to the hospital. }\end{array}$ \\
\hline
\end{tabular}

\section{PENDAHULUAN}

Pada akhir tahun 2019 seluruh dunia dihadapkan dengan pandemi COVID-19, yang telah menyebabkan tantangan besar terhadap perawatan penyakit tidak menular seperti diabetes mellitus dan komplikasinya [1].
Diabetic Foot ulcer (DFU) merupakan komplikasi utama dari Diabetes mellitus yang berhubungan dengan tingginya morbiditas dan mortalitas dan penyebab utama penderita diabetes dirawat dirumah sakit [2], dimana 40-60 juta orang dengan DM mengalami Diabetic Foot Ulcer (DFU). Prevalensi diabetic foot ulcer (DFU) secara global yaitu 6,4 \%, Amerika utara $13 \%$, Asia

Corresponding author:

Yulius Tiranda

yuliustiranda@ikestmp.ac.id

Media Keperawatan Indonesia, Vol 4 No 4, November 2021

e-ISSN: 2615-1669

ISSN: 2722-2802

DOI: $10.26714 / \mathrm{mki} .4 .4 .2021 .311-322$ 
$5,5 \%$, Eropa 5,1 \%, prevalensi pada pria lebih tinggi dari wanita yaitu $4,5 \%$ dan 3,5 $\%$ [3]. Di Indonesia, prevalensi diabetic foot ulcer (DFU) sekitar 15\%, risiko amputasi $30 \%$, dan angka kematian $32 \%$, yang merupakan penyebab terbesar rawat inap $80 \%$ [4].

Fasilitas pelayanan kesehatan membuat kekhawatiran pada masyarakat di masa pandemi COVID-19, seperti cemas untuk datang kepelayanan kesehatan karena takut terpapar virus COVID-19 [5]. Rumah sakit merupakan salah satu fasilitas layanan kesehatan yang berfokus pada penanggulangan keadaan darurat COVID19 telah mengurangi aktivitas rawat inap dan rawat jalan sehingga banyak pasien tanpa perawatan. Pelayanan kesehatan selama masa pandemi COVID-19, mengurangi pelayanan kesehatan bagi pasien biasa (pasien non-COVID-19) untuk fokus pada penyediaan layanan pasien COVID-19. Namun, pasien dengan diabetic foot ulcer memerlukan rawat inap atau perawatan karena adanya iskemia dan infeksi, dan rujukan dini untuk mengurangi amputasi dan kematian [6].

Pelayanan Kesehatan sebagai sektor yang paling terdampak pandemic harus siap beradaptasi dengan kebiasaan baru yang muncul akibat COVID-19. Rumah sakit harus mempertimbangkan langkah-langkah untuk tetap merawat pasien COVID-19, tetapi pada saat yang sama memberikan pelayanan kepada pasien biasa dan meminimalkan resiko penularan [7]. Sistem pelayanan kesehatan dan perawatan pasien dengan luka diabetic foot ulcer harus tetap dirawat namun harus meminimalkan kebutuhan untuk mengunjungi rumah sakit untuk mengurangi resiko tertular COVID-19 [8].

Berdasarkan penelitian sebelumnya bahwa pelayanan pelayanan kesehatan terhadap pasien Diabetic foot ulcer dalam masa pandemi yaitu dilakukan dengan metode konsultasi online via pesan singkat seperti WeChat [9], melakukan skrininng atau pengkajian pada pasien DFU untuk melihat ada atau tidak infeksi [10]. Adanya perbedaan dalam pelayanan pada pasien diabetic foot ulcer di masa pandemi COVID19, oleh karena itu peneliti tertarik mengetahui tentang pelayanan kesehatan pada pasien diabetic foot ulcer dalam masa pandemi COVID-19. Tujuan literature review ini untuk mengeksplorasi pelayanan kesehatan pada pasien Diabetic foot ulcer dalam Masa Pandemi COVID-19.

\section{METODE}

\section{Desain Penelitian}

Penelitian ini menggunakan pendekatan literature review. Data diperoleh dari 6 database elektronik yaitu Perpusnas, Pubmed, Science direct, ProQuest, Spring nature, dan Wiley, antaratahun 2019-2021. Kata kunci yang digunakan antara lain : diabetic foot ulcer or diabetic foot or foot ulcer AND Health service or healthcare system or management system or management service AND COVID-19 or coronavirus disease or Sars-Cov-2. Kriteria Inklusi antara lain :Pasien Diabetic foot ulcer, Fulltext, Academic Journal, Tahun Publikasi 2019-2021.

\section{Strategi Pencarian}

Strategi Pencarian dalam studi ini menggunakan 6 database elektronik yaitu Perpusnas, Pubmed, Science Direct, ProQuest, Springer Nature dan Wiley dari tahun 20192021. Pencarian artikel menggunakan kata kunci yang sudah disesuaikan dengan Medical Subject Heading (MeSH) untuk mempermudah dalam menyaring artikel. Kata kunci yaitu : diabetic foot ulcer or diabetic foot or foot ulcer AND Health service or healthcare system or management system or management service AND COVID-19 or coronavirus disease or Sars-Cov-2.

\section{Seleksi Studi}

Peneliti menggunakan Prisma Guideline dalam proses seleksi studi. Pertama yaitu 
mengidentifikasi artikel menggunakan enam database elektronik yang terdiri dari Perpusnas (533), Pubmed (18), Science direct (4), ProQuest (42), Springer nature (23) dan Wiley (49) dan total seluruh artikel yaitu 669 artikel. Duplikasi ditemukan terdapat 104 artikel. Selanjutnya 565 artikel di skrining dengan membaca detail judul atau abstrak.

Selanjutnya 565 artikel di skrining dengan membaca detail judul atau abstrak berdasarkan kriteria : artikel full-text, antara tahun 2019-2021, bahasa inggris, akademik jurnal, diabetic foot ulcer, covid19, healthcare service. Pada langkah ini 475 artikel dikeluarkan karena tidak memenuhi criteria inklusi : COVID-19 secara umum (353), Perawatan kanker di masa COVID-19 (6), COVID-19 dan Komorbid DM (62), Pengaruh COVID-19 dan pasien pneumonia (22), Sistem Imun dan COVID-19 (6), Medical (26), dan lain-lain (38) sehingga tersisa 52 artikel.

Tahap selanjutnya, 52 artikel tersebut ditinjau secara fulltext dan dibaca sebanyak 3 kali sehingga didapatkan 40 artikel yang dikeluarkan karena tidak memenuhi syarat untuk digunakan dalam literature review: systematic review, meta-analysis, dan review, dan artikel yang tidak menjawab tujuan penelitian. Maka, ditetapkan 12 yang memenuhi syarat untuk digunakan dalam literature review.

\section{Penilaian Artikel}

Proses penilaian artikel dilakukan dengan membaca 52 artikel judul/abstrak, fulltext sebanyak 3 kali dan didapatkan 7 artikel yang dipilih, selanjutnya peneliti melakukan validasi kepada pembimbing guna mendapatkan analisis lebih baik. Setelah pembimbing melakukan pengecekan dan menganalisis artikel tersebut, pembimbing menambahkan 5 artikel untuk dilakukan pengecekan kembali oleh peneliti sebagai tambahan untuk di review. Peneliti membaca 5 artikel yang di tambahkan oleh pembimbing.
Setelah dilakukan pengecekan ulang oleh peneliti dan mendapat masukan dan validasi dari pembimbing, maka berdasarkan kesepakatan bersama antara peneliti dan pembimbing, didapatkan sebanyak 12 artikel yang akan direview. 


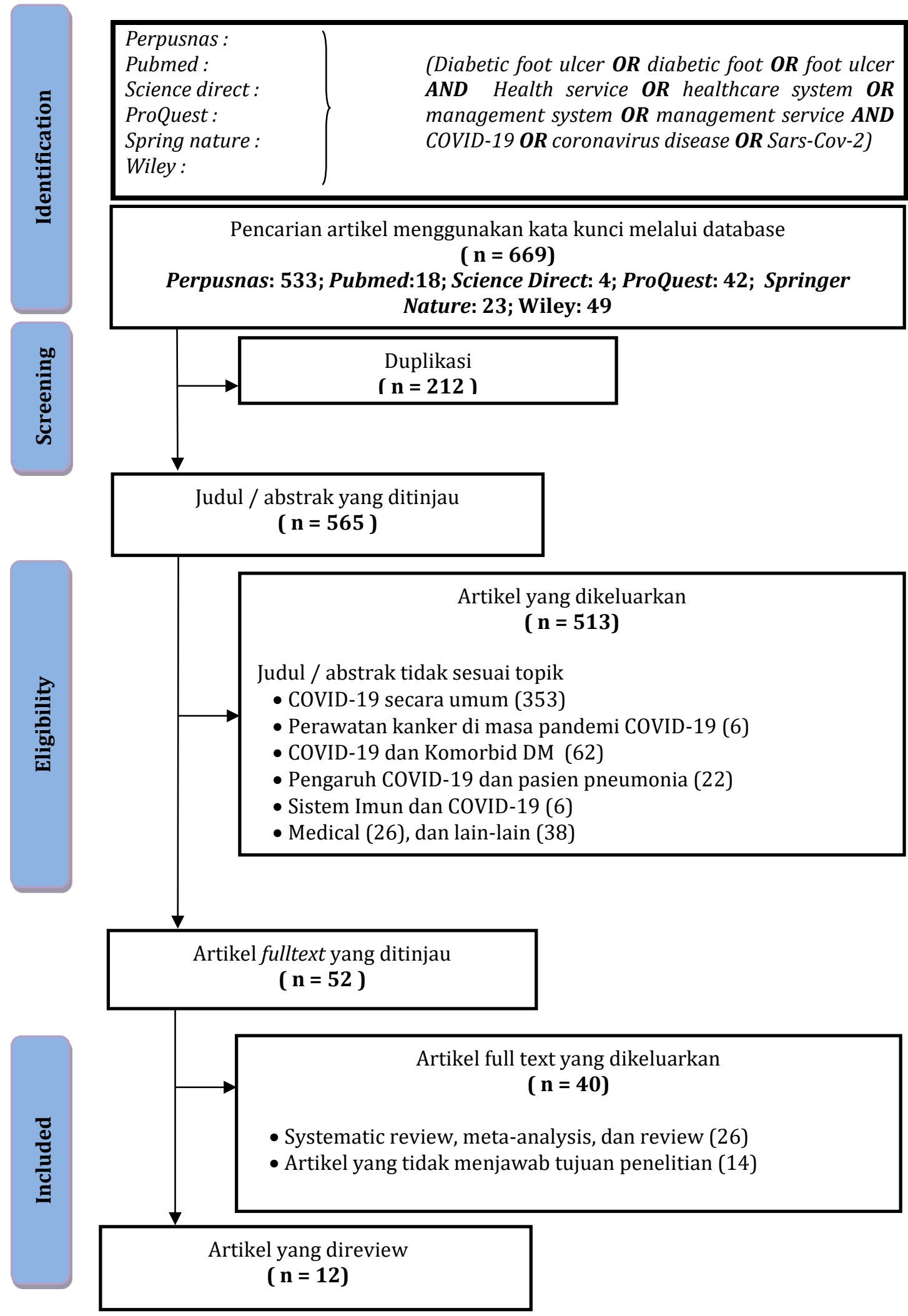

Gambar1

Proses Seleksi Literature Review (PRISMA Guideline) 


\section{HASIL}

Penelitian Liu et al (2020) menyatakan bahwa Pelayanan Kesehatan untuk pasien Diabetic foot ulcer dapat dilakukan dengan konsultasi online sistem konsultasi jarak jauh atau Telemedicine melalui pesan instan (mis. WeChat, dll.) [9]. Sedangkan menurut penelitian Jaly et al (2020)Konsultasi tatap muka (face to face ) dapat dilakukan pada pasien dengan diabetic foot yang mempunyai gejala aktif atau tanda infeksi misalnya infeki, nyeri, bengkak, Pasien dengan tanda / gejala yang menunjukkan ulkus iskemik, dan Pasien dengan alat bantu jalan yang tidak dapat dilepas yang memerlukan bantuan oleh seorang profesional untuk memfasilitasi perawatan kaki [11].

Ratliff et al (2020) menyatakan bahwa Layanan Telemedicine membantu memberikan perawatan yang diperlukan kepada pasien dengan meminimalkan risiko penularan virus corona terhadap petugas kesehatan dan pasien [12]. Hal ini sejalan dengan penelitian Atri et al (2020) bahwa perubahan praktik ke pendekatan yang didorong oleh telemedicine, dengan penekanan pada perawatan rumah dan klinik komunitas, perlu diadopsi, untuk memastikan perawatan terbaik bagi pasien dengan DFU, untuk mengurangi risiko komplikasi terkait DFU dan kebutuhan rawat inap [13].

Penelitian Schmidt et al (2020) meyebutkan Penerapan protokol STRIDE efektif untuk triase semua pasien diabetes dengan komplikasi ulkus kaki diabetik dan dapat mencegah peningkatan rawat inap dan amputasi [14]. Sejalan dengan Penelitian Kesavan et al (2020) bahwa Pada saat triase, pengkajian harus dilakukan tentang kemungkinan gejala COVID-19 batuk atau sakit tenggorokan atau demam. Setiap pasien dengan gejala sesak demam, takikardia, dan sepsis (bisa juga karena COVID 19) harus dirujuk ke rumah sakit dengan fasilitas unit perawatan intensif (ICU) [15].
Menurut Oropallo et al (2020) Sistem Triase dilakukan sesuai dengan kondisi pasien. Kelompok prioritas satu : pasien dengan Infeksi parah harus mendapatkan perawatan dirumah sakit, kelompok prioritas dua: Pasien dengan infeksi ringan harus mendapatkan perawatan di klinik rawat jalan, Kelompok prioritas ketiga : pasien dengan ulkus kaki yang membaik dapat dirawat di rumah atau melalui telemedicine [16]. Sedangkan menurut penelitian Meloni et al (2020) Jalur Triase spesifik yang di digunakan di unit kaki diabetik menunjukkan hasil jangka awal yang baik dengan penurunan kasus amputasi dan mortalitas mayor, dan tidak ada infeksi COVID-19 yang diakibatkan oleh rumah sakit [6].

Kelahmetoglu et al (2020) menyebutkan bahwa Skrining dan pemeriksaan COVID19 untuk Pasien Diabetic foot Ulcer dilakukan dengan menanyakan secara cermat tentang demam, batuk, dan gangguan pernapasan atau apakah terinfeksi COVID-19, mengevaluasi tandatanda vital pasien (demam, nadi, tekanan darah,dan pernapasan). Dan mengevaluasi luka dan derajat infeksi. Jika tidak ada infeksi atau infeksi ringan pada luka, dan tidak ada demam, perawatan luka lokal sudah cukup di rumah dan konsultasi online mingguan dapat direncanakan dengan menggunakan WhatsApp (WhatsApp Inc., California), Jika intervensi bedah mendesak diperlukan: pemeriksaan CT Scan Thorax sebelum pembedahan [10].

Tao et al (2020) menyebutkan bahwa Tes darah dan CT Scan dada direkomendasikan sebagai pemeriksaan rutin karena dapat memfasilitasi skrining COVID-19 yang cepat dan akurat [17]. Menurut Kavitha et al (2020) bahwa Telemedicine adalah alat skrining yang baik untuk mendiagnosis dan mengelola pasien berisiko dengan diabetic foot dan juga memungkinkan sistem triaging untuk memutuskan kunjungan rumah sakit dan rawat inap [18]. Sejalan dengan penelitian Shin et al (2020) bahwa Semua pasien dengan Diabetic foot ulcer 
datang ke UGD akan menjalani skrining untuk COVID-19, termasuk mereka yang memiliki kemungkinan osteomyelitis [1].

Berdasarkan dari 12 artikel didapatkan bahwa semua artikel menggunakan metode penelitian deskriptif, case study report dan longitudinal study. Tempat dari penelitian artikel tersebut antara lain, Lima artikel di
India, satu artikel di Turki, dua artikel di China, satu artikel di Italia, dua artikel di Amerika, dan satu artikel di Virginia. Hasil analisis dari 12 artikel didapatkan bahwa pelayanan kesehatan pada pasien Diabetic foot ulcer (DFU) terdiri dari konsultasi online (telemedicine), menentukan Triase, Skrining pasien dan penggunaan Telemedicine untuk perawatan lanjutan.

Tabel 1.

Ekstraksi Data Hasil Pencarian Literature Review

\begin{tabular}{|c|c|c|c|c|c|}
\hline No & Author & Judul & Tujuan & Desain & Hasil \\
\hline 1 & $\begin{array}{l}\text { (Meloniet } \\
\text { al., 2020) }^{1}\end{array}$ & $\begin{array}{l}\text { Management of } \\
\text { diabetic persons } \\
\text { with foot } \\
\text { ulceration during } \\
\text { COVID-19 health } \\
\text { care } \\
\text { emenrgency: } \\
\text { Effectiveness of a } \\
\text { new triage } \\
\text { pathway }\end{array}$ & $\begin{array}{l}\text { Untuk mengevaluasi } \\
\text { Karakteristik klinis dan } \\
\text { menentukan hasil pasien } \\
\text { denganDFU yang dikelola } \\
\text { melalui protocol khusus } \\
\text { (Jalur Triase) selama krisis } \\
\text { COVID-19 }\end{array}$ & Deskriptif & $\begin{array}{l}\text { Jalur Triasespesifik yang di } \\
\text { digunakan di unit kaki diabetic } \\
\text { menunjukkan hasil jangka awal } \\
\text { yang baik dengan penurunan } \\
\text { kasus amputasi dan mortalitas } \\
\text { mayor, dan tidak ada infeksi } \\
\text { COVID-19 yang diakibatkan oleh } \\
\text { rumah sakit. }\end{array}$ \\
\hline 2 & $\begin{array}{l}\text { (Jalyet al., } \\
2020)^{2}\end{array}$ & $\begin{array}{l}\text { Redefiniting } \\
\text { diabetic foot } \\
\text { disease } \\
\text { management } \\
\text { service during } \\
\text { COVID-19 } \\
\text { pandemic }\end{array}$ & $\begin{array}{l}\text { Untuk mengevaluasi } \\
\text { dampak COVID-19 } \\
\text { terhadap pelayanan } \\
\text { diabetic foot ulcer (DFU) } \\
\text { dan strategi atau langkah- } \\
\text { langkah yang diambil oleh } \\
\text { pelayanan kesehatan } \\
\text { untuk mengatasinya. }\end{array}$ & Deskriptif & $\begin{array}{l}\text { Mendukung dan mengelola } \\
\text { pasien dengan DFU dengan } \\
\text { telemedicine untuk membantu } \\
\text { memantau via jarak jauh bagi } \\
\text { pasien yang membutuhkan } \\
\text { perawatan dan membuat Triase }\end{array}$ \\
\hline 3 & $\begin{array}{l}\text { (Kelahmetog } \\
\text { luet al., } \\
2020)^{3}\end{array}$ & $\begin{array}{l}\text { Recommendation } \\
\mathrm{s} \text { for management } \\
\text { of diabetic foot } \\
\text { ulcers during } \\
\text { COVID-19 } \\
\text { outbreak }\end{array}$ & $\begin{array}{l}\text { Untuk memanajemen } \\
\text { Algoritma mencegah } \\
\text { Komplikasi tak terduga } \\
\text { Yang dapat terjadi pada } \\
\text { pasien dan petugas } \\
\text { kesehatan selama evaluasi } \\
\text { COVID-19 pada pasien } \\
\text { DFU. }\end{array}$ & Deskriptif & $\begin{array}{l}\text { Merekomendasikan penggunaan } \\
\text { CT thorax dan skrining pada } \\
\text { semua pasien DFU dengan yang } \\
\text { memiliki tanda-tanda infeksi dan } \\
\text { terutama yang membutuhkan } \\
\text { pembedahan segera untuk } \\
\text { mendeteksi kemungkinan tidak } \\
\text { terdiagnosis COVID-19 pada } \\
\text { pasien. }\end{array}$ \\
\hline 4 & $\begin{array}{l}\text { (Schmidt et } \\
\text { al., 2020) }\end{array}$ & $\begin{array}{l}\text { Strategies to } \\
\text { reduce severe } \\
\text { diabetic foot } \\
\text { infections and } \\
\text { complications } \\
\text { during epidemics } \\
\text { (STRIDE) }\end{array}$ & $\begin{array}{l}\text { Untuk mengembangkan } \\
\text { algoritma Triase secara } \\
\text { efektif untuk semua pasien } \\
\text { DFU, mengurangi potensi } \\
\text { komplikasi, dan untuk } \\
\text { menilai kelayakan } \\
\text { perawatan secara virtual } \\
\text { untuk DFU. }\end{array}$ & $\begin{array}{l}\text { Longitudi } \\
\text { nal study }\end{array}$ & $\begin{array}{l}\text { Penerapan protokol STRIDE } \\
\text { efektif untuk triase semua pasien } \\
\text { diabetes dengan komplikasi ulkus } \\
\text { kaki diabetik dan dapat mencegah } \\
\text { peningkatan rawat inap dan } \\
\text { amputasi. }\end{array}$ \\
\hline 5 & $\begin{array}{l}\text { (Tao et al., } \\
2020)^{5}\end{array}$ & $\begin{array}{l}\text { Surgical } \\
\text { treatment of } \\
\text { diabetic foot } \\
\text { ulcers during the } \\
\text { COVID-19 } \\
\text { pandemic in } \\
\text { China }\end{array}$ & $\begin{array}{l}\text { Menjelaskan strategi yang } \\
\text { diusulkan untuk diagnosis } \\
\text { dan pengobatan DFU } \\
\text { berdasarkan pengalaman } \\
\text { strategi pengendalian } \\
\text { infeksi COVID-19 di Cina. }\end{array}$ & Deskriptif & $\begin{array}{l}\text { Skrining dan penatalaksanaan } \\
\text { awal COVID-19 pada pasien } \\
\text { dengan DFU : apakah setiap } \\
\text { pasien memiliki riwayat pajanan } \\
\text { ke daerah yang terkena COVID-19 } \\
\text {,dan lain lain. Dan Semua pasien } \\
\text { harus menjalani pemeriksaan CT } \\
\text { Thorax, PCR dan tes darah dan } \\
\text { pemeriksaan lainnya. }\end{array}$ \\
\hline
\end{tabular}




\begin{tabular}{|c|c|c|c|c|c|}
\hline 6 & $\begin{array}{l}\text { (Kavitha et } \\
\text { al., 2020) }\end{array}$ & $\begin{array}{l}\text { Application of } \\
\text { tele-podiatry in } \\
\text { diabetic foot } \\
\text { management : A } \\
\text { series of } \\
\text { illustrative cases }\end{array}$ & $\begin{array}{l}\text { Melaporkan pengalaman } \\
\text { dalam mengelola tiga } \\
\text { kasus yang bervariasidari } \\
\text { kaki diabetik, menjelaskan } \\
\text { kelayakankonsep 'triase' } \\
\text { dan juga telemedicine } \\
\text { atau "tele-podiatri" dalam } \\
\text { manajemen kaki diabetik. }\end{array}$ & $\begin{array}{l}\text { Case Study } \\
\text { report }\end{array}$ & $\begin{array}{l}\text { Tele-podiatri efektif dalam } \\
\text { pengelolaan pasien dengan ulkus } \\
\text { kaki diabetik, dan juga berguna } \\
\text { dalam rujukan untuk kunjungan } \\
\text { kerumahsakit / klinik, } \\
\text { memfasilitasi manajemen yang } \\
\text { tepat. }\end{array}$ \\
\hline 7 & $\begin{array}{l}\text { (Atriet al., } \\
2020)^{7}\end{array}$ & $\begin{array}{l}\text { Managing } \\
\text { diabetic foot in } \\
\text { times of COVID- } \\
\text { 19: time to put } \\
\text { the best "foot } \\
\text { forward" }\end{array}$ & $\begin{array}{l}\text { Untuk menganalisis } \\
\text { hubungan antara infeksi } \\
\text { COVID-19 dan DFU yang } \\
\text { merupakan komplikasi } \\
\text { yang cukup umum, namun } \\
\text { serius pada pasien } \\
\text { diabetes, serta } \\
\text { manajemennya }\end{array}$ & Deskriptif & $\begin{array}{l}\text { Sistem perawatan } \\
\text { pada masa pandemi COVID-19 } \\
\text { dilakukan perubahan praktik } \\
\text { oleh telehealth, untuk } \\
\text { memastikan perawatan terbaik } \\
\text { bagi pasien dengan DFU, untuk } \\
\text { mengurangi risiko komplikasi } \\
\text { terkait DFU dan kebutuhan rawat } \\
\text { inap. }\end{array}$ \\
\hline 8 & $\begin{array}{l}\text { (Shin et al., } \\
2020)^{8}\end{array}$ & $\begin{array}{l}\text { Saving the } \\
\text { Diabetic Foot } \\
\text { During the } \\
\text { COVID-19 } \\
\text { Pandemic: A Tale } \\
\text { of Two Cities }\end{array}$ & $\begin{array}{l}\text { Untuk mendeskripsikan } \\
\text { langkah-langkah yang } \\
\text { diambil dalam mengelola } \\
\text { masalah kaki diabetik dan } \\
\text { untuk mencegah perlunya } \\
\text { rawat inap dirumah sakit } \\
\text { jika memungkinkan }\end{array}$ & $\begin{array}{l}\text { Case } \\
\text { Report }\end{array}$ & $\begin{array}{l}\text { Perawatan untuk pasien DFU } \\
\text { pada kasus menggunakan } \\
\text { konsultasi telemedicine telah } \\
\text { terbukti berhasil walau } \\
\text { merupakan perkembangan baru } \\
\text { dalam manajemen DFU. }\end{array}$ \\
\hline 9 & $\begin{array}{l}\text { (Liu et al., } \\
2020)^{9}\end{array}$ & $\begin{array}{l}\text { An internet- } \\
\text { based algorithm } \\
\text { for diabetic foot } \\
\text { infection during } \\
\text { the COVID-19 } \\
\text { pandemic }\end{array}$ & $\begin{array}{l}\text { Untuk mengembangkan } \\
\text { sistem berbasis untuk } \\
\text { menanggapi kebutuhan } \\
\text { kesehatan masyarakat } \\
\text { yang mendesak. }\end{array}$ & Deskriftif & $\begin{array}{l}\text { Menyediakan layanan konsultasi } \\
\text { online untuk pasien dengan DFU } \\
\text { melalui pesan instan (mis. } \\
\text { WeChat, dll.), Platform jaringan, } \\
\text { dan sistem konsultasi jarak jauh } \\
\text { menggunakan algoritma untuk } \\
\text { mengoptimalkan perawatan } \\
\text { ataupun follow up. }\end{array}$ \\
\hline 10 & $\begin{array}{l}\text { (Kesavanet } \\
\text { al., 2020)10 }\end{array}$ & $\begin{array}{l}\text { Guidance for } \\
\text { Diabetic Foot } \\
\text { Management } \\
\text { during COVID-19 } \\
\text { Pandemic }\end{array}$ & $\begin{array}{l}\text { Untuk mengelola pasien } \\
\text { dengan Diabetic foot dan } \\
\text { menerapkan cara- cara } \\
\text { baru dan untuk } \\
\text { kebutuhan saat ini di saat } \\
\text { krisis pandemi COVID-19. }\end{array}$ & Deskriftif & $\begin{array}{l}\text { Pengelolaan pasie DFU dapat } \\
\text { dilakukan dengan menerapkan } \\
\text { sistem Skirining untuk melihat } \\
\text { tentang kemungkinan gejala } \\
\text { COVID-19 dan TRIASE untuk } \\
\text { prioritas kebuthan pasien. }\end{array}$ \\
\hline 11 & $\begin{array}{l}\text { (Ratliff et } \\
\text { al., 2020)11 }\end{array}$ & $\begin{array}{l}\text { Telehealth for } \\
\text { Wound } \\
\text { Management } \\
\text { During the } \\
\text { COVID-19 } \\
\text { Pandemic }\end{array}$ & $\begin{array}{l}\text { Untuk meminimalkan } \\
\text { layanan klinis terkait dari } \\
\text { kunjungan klinik rawat } \\
\text { jalan kekunjungan } \\
\text { telehealth. }\end{array}$ & $\begin{array}{l}\text { Case Study } \\
\text { report }\end{array}$ & $\begin{array}{l}\text { Dua laporan kasus pasien dengan } \\
\text { luka yang dikelola dengan } 2 \\
\text { platform telehealth berfungsi } \\
\text { baik dalam } \text { pengaturan } \\
\text { perawatan }\end{array}$ \\
\hline 12 & $\begin{array}{l}\text { (Oropalloet } \\
\text { al., 2020)12 }\end{array}$ & $\begin{array}{l}\text { Wound care } \\
\text { during the } \\
\text { COVID-19 } \\
\text { pandemic: } \\
\text { improving } \\
\text { outcomes } \\
\text { through the } \\
\text { integration of } \\
\text { telemeedicine }\end{array}$ & $\begin{array}{l}\text { Mengintegrasikan } \\
\text { Telemedicine kedalam } \\
\text { perawatan luka selama } \\
\text { wabah, membantu } \\
\text { menjaga jarak sosial, } \\
\text { menjaga peralatan } \\
\text { pelindung diri dan } \\
\text { melindungi dari paparan } \\
\text { pasien yang rentan dan } \\
\text { petugas perawatan } \\
\text { kesehatan yang berisiko } \\
\text { tinggi. }\end{array}$ & Deskriptif & $\begin{array}{l}\text { Hasil penelitian menunjukkan } \\
\text { telemedicine efektif dalam } \\
\text { manajemen pasien DFU dan dapat } \\
\text { dilakukan system triase untuk } \\
\text { kelompok prioritas pasien }\end{array}$ \\
\hline
\end{tabular}




\section{PEMBAHASAN}

\section{Konsultasi Online/ Telemedicine}

Layanan Telemedicine membantu memberikan perawatan yang diperlukan kepada pasien dengan meminimalkan risiko penularan virus corona kepetugas kesehatan dan pasien. Perubahan kebijakan selama pandemi COVID-19 telah mempromosikan penggunaan telemedicine sebagai cara untuk memberikan perawatan kesehatan [19].

Sistem telemedicine diterapkan dan digunakan oleh perawat untuk mengumpulkan data dan mengambil gambar dari luka tersebut. Informasi yang dikumpulkan oleh perawat kemudian dikirim ke dokter untuk pengambilan keputusan. Data yang dikumpulkan meliputi pertanyaan tentang kualitas hidup, seperti gizi, pergerakan dan tingkat nyeri, serta kepuasan pasien terhadap pengobatan. Setelah itu, spesialis perawatan luka akan mengirimkan saran pengobatan kepada perawat dan pasien [20].

Pandemi COVID-19 yang sedang terjadi telah menyebabkan tantangan bagi pengelolaan diabetes, dan khususnya masalah diabetic foot ulcer. Pada saat yang sama, telah menciptakan peluang untuk mengimplementasikan solusi telemedicine. Keuntungan telemedicine adalah: a) dapat diakses dari rumah menggunakan smartphone, tablet, atau komputer; b) ekonomis; c) Dapat membantu dalam berbagai kondisi medis [21].

Banyak penelitian telah menunjukkan bahwa telemedicine telah berhasil diterapkan untuk meningkatkan hasil pada pasien diabetes. Telemedicine lebih efektif dalam meningkatkan hasil pengobatan untuk pasien diabetes, terutama bagi mereka dengan diabetes tipe 2 [22]. Garg et al menemukan bahwa telemedicine sebagai pendekatan yang efektif untuk pengelolaan pasien dengan diabetes dan komplikasinya yaitu diabetic foot ulcer selama pandemi COVID-19 [23].

\section{Triage}

Triage atau triase adalah proses pengutamaan pelayanan pasien berdasarkan berat ringannya kondisi pasien. Triage adalah proses penggolongan pasien menurut jenis dan tingkat keparahan kondisinya. Triage mencakup semua staf; terutama dokter dan perawat. Tujuannya adalah untuk mengidentifikasi semua pasien dengan DFU dan dengan potensi resiko komplikasi DFU [14].

Pada saat triase, prioritas perawatan pasien tergantung pada tingkat keparahan kondisinya. Merah: Menunjukkan keadaan kritis dan diambil sebagai prioritas pertama. Oranye: Menunjukkan situasi darurat dan merupakan prioritas kedua. Kuning: Menunjukkan bahwa perhatian ekstra perlu dilakukan dan merupakan prioritas ketiga. Hijau: Menunjukkan situasi yang stabil [24].

Rogers et al menyarankan system triase untuk luka ekstremitas dan masalah kaki diabetes selama pandemi. Infectious Disease Society of America (IDSA) mengkategorikan pasien dengan infeksi sedang, gangren, sepsis dan iskemia akut yang mengancam tungkai dalam kelompok prioritas satu. Pasien-pasien ini harus mendapatkan perawatan di rumah sakit. Pasien dengan infeksi sedang termasuk osteomielitis, iskemia tungkai kronis, gangren kering, ulkus kaki yang memburuk, dan kaki Charcot aktif dikategorikan dalam kelompok prioritas dua. Pasien-pasien ini harus mendapatkan perawatan di klinik rawat jalan. Dalam kelompok prioritas ketiga, pasien dengan ulkus kaki yang membaik dapat menerima perawatan di rumah dan melalui telemedicine. Dalam kelompok prioritas empat, pasien stabil, yang mewakili 94\% penderita diabetes dengan luka kaki, dapat dirawat di rumah atau melalui telemedicine [25]. 


\section{Skrining}

Skrining adalah memprediksi karakteristik penyakit atau kelainan yang tidak diketahui melalui tes, pemeriksaan atau prosedur lain yang dapat diselesaikan dengan cepat, sehingga dapat mengklasifikasikannya kedalam penyakit atau tidak. Pasien harus diskrining terlebih dahulu sebelum bertemu dengan dokter [26].

Diagnosis serta manajemen yang aman untuk semua DFU membutuhkan pengecualian COVID-19 sekaligus mengurangi kontak antara personel dan peralatan, serta pencegahan infeksi nosokomial. Selama wabah COVID19 yang parah, bagian gawat darurat dan rawat jalan harus dengan hati-hati menentukan apakah setiap pasien memiliki riwayat pajanan kedaerah yang terkena, apakah pasien dicurigai, riwayat kontak dengan individu yang mengidap COVID-19, dan apakah pasien menunjukkan gejala COVID-19 seperti demam, batuk, dispnea, dan kelemahan [17].

Pasien dengan Diabetic foot ulcer (DFU) juga mungkin mengalami gejala demam biasanya disertai dengan kemerahan lokal, bengkak, nyeri, inflamasi. Pasien yang memenuhi kriteria diagnostic untuk dicurigai COVID-19 harus dipindahkan kerumah sakit yang ditunjuk sesegera mungkin. Jika unit memiliki rawat inap bersyarat atau pasien yang terinfeksi tidak dapat segera dipindahkan, pasien yang terinfeksi harus diisolasi secara mandiri dan staf medis harus menggunakan perlindungan tingkat tiga, yang mengacu pada penggunaan masker pelindung N95, pakaian pelindung, , sepatu, sarung tangan, serta kacamata dan pelindung pernapasan [27].

Pasien dengan suspek COVID-19 harus dipindahkan ke bangsal isolasi jika mereka menunjukkan tanda-tanda vital yang stabil. Setelah dirawat di rumah sakit, kadar glukosa darah pasien harus dikontrol secara aktif selama pengobatan COVID-19; dukungan nutrisi harus diperkuat; dan antibiotik. Untuk pasien dengan DFU yang relative kecil yang terkait dengan infeksi ringan (Wagner grade I dan II), dokter dapat melakukan debridement sederhana dengan anestesi lokal, menggunakan tindakan perlindungan level tiga di bangsal isolasi. Penggantian balutan luka secara teratur dan balutan baru untuk ulkus juga harus disediakan sesuai kebutuhan [28]. 




Gambar 2

Pelayanan pasien Diabetic foot ulcer (DFU) pada masa Pandemi COVID-19 


\section{SIMPULAN}

COVID-19 telah menyebabkan gangguan pada pelayanan dan perawatan kesehatan di seluruh dunia yang menghadirkan tantangan besar bagi petugas layanan kesehatan. Pasien dengan diabetic foot ulcer (DFU) memiliki resiko untuk terinfeksi COVID-19 sehingga diperlukan solusi untuk memberikan pelayanan kesehatan dan perawatan luka yang optimal namun tetap meminimalkan kunjungan rumah sakit untuk meminimalkan resiko terpapar COVID-19. Sistem pelayanan dan perawatan kesehatan dapat dilakukan dengan melakukan triage, mengevaluasi, dan merawat pasien menggunakan telemedicine agar tidak bergantung melakukan kunjungan rumah sakit secara langsung selama pandemi COVID-19. Konsultasi Telemedicine telah memberi kesempatan untuk mengelola pasien dari jarak jauh dan membuat keputusan dengan melakukan triage mengenai siapa yang membutuhkan perawatan tatap muka, rawat inap ataupun perawatan dirumah.

\section{UCAPAN TERIMAKASIH}

Penulis mengucapkan terimakasih kepada semua pihak yang telah membantu dalam penyusunan literature review ini.

\section{REFERENSI}

[1] Shin L, Bowling FL, Armstrong DG, Boulton AJM. Saving the diabetic foot during the COVID-19 pandemic: A tale of two cities. Diabetes Care 2020;43:1704-9.

https://doi.org/10.2337/dc20-1176.

[2] IDF. IDF Diabetes Atlas Ninth Edition 2019. 9th ed. 2019.

[3] IWGDF. IWGDF Guidelines on the Prevention and Management of Diabetic Foot Disease. 2019.

[4] Purwanti LE, Maghfirah S. Faktor Risiko Komplikasi Kronis (Kaki Diabetik) Dalam Diabetes Mellitus Tipe 2. Indones J Heal Sci 2016;7:26-39.

[5] Harahap DR, Utami TN. Persepsi Masyarakat Terhadap Kualitas Pelayanan Kesehatan pada Masa Pandemi COVID-19 di Kota Binjai. J Penelit Kesehat Suara Forikes 2021;12:162-5. https://doi.org/http://dx.doi.org/10.33846/sf 12211.

[6] Meloni M, Izzo V, Giurato L, Gandini R, Uccioli L. Management of diabetic persons with foot ulceration during COVID-19 health care emergency: Effectiveness of a new triage pathway. Diabetes Res Clin Pract 2020. https://doi.org/https://doi.org/10.1016/j.dia bres.2020.108245.

[7] KEMENKES RI. Panduan Teknis Pelayanan Rumah Sakit Pada Masa Adaptasi Kebiasaan Baru. Jakarta: Direktorat Pelayanan Kesehatan Rujukan Direktorat Jenderal Pelayanan Kesehatan Kementerian Kesehatan RI; 2020.

[8] Caruso P, Longo M, Signoriello S, Gicchino M, Maiorino MI, Bellastella G, et al. Diabetic foot problems during the COVID-19 pandemic in a tertiary care center: The emergency among the emergencies. Diabetes Care 2020. https://doi.org/https://doi.org/10.2337/dc20 $-1347$.

[9] Liu C, Shi WL, You JX, Li HY, Li L. An internetbased algorithm for diabetic foot infection during the COVID-19 pandemic. J Foot Ankle Res 2020;13. https://doi.org/10.1186/s13047020-00405-z.

[10] Kelahmetoglu O, Camlı MF, Kirazoglu A, Erbayat $\mathrm{Y}$, Asgarzade $\mathrm{S}$, Durgun $\mathrm{U}$, et al. Recommendations for management of diabetic foot ulcers during COVID-19 outbreak. Int Wound J 2020;17:1424-7. https://doi.org/10.1111/iwj.13416.

[11] Jaly I, Iyengar K, Bahl S, Hughes T, Vaishya R. Redefining diabetic foot disease management service during COVID-19 pandemic. Diabetes Metab Syndr Clin Res Rev 2020:833-8. https://doi.org/https://doi.org/10.1016/j.dsx. 2020.06.023.

[12] Ratliff CR, Shifflett R, Howell A, Kennedy C. Telehealth for wound management during the Covid-19 pandemic: Case studies. J Wound, Ostomy Cont Nurs 2020;47:445-9. https://doi.org/10.1097/WON.000000000000 0692.

[13] Atri A, Kocherlakota CM, Dasgupta R. Managing diabetic foot in times of COVID-19: time to put the best 'foot' forward. Int J Diabetes Dev Ctries 2020;40:321-8. https://doi.org/10.1007/s13410-020-008669.

[14] Schmidt BM, Munson ME, Rothenberg GM, Holmes CM, Pop-Busui R. Strategies to reduce severe diabetic foot infections and complications during epidemics (STRIDE). J Diabetes 2020;34. https://doi.org/https://doi.org/10.1016/j.jdia comp.2020.107691. 
[15] Kesavan R, Murthy N, Rastogi A, Bal A. Guidance for Diabetic Foot Management during COVID-19 Pandemic. Indian J Vasc Endovasc Surg 2020:116-20.

https://doi.org/10.4103/ijves.ijves.

[16] Oropallo A, Lantis J, Martin A, Al Rubaiay A, Wang $N$. Wound care during the COVID-19 pandemic: improving outcomes through the integration of telemedicine. J Wound Care 2021;30.

[17] Tao F, Tang X, Tao H, Luo Y, Cao H, Xiang W, et al. Surgical treatment of diabetic foot ulcers during the COVID-19 pandemic in China. J Diabetes Complications 2020;34. https://doi.org/10.1016/j.jdiacomp.2020.107 622.

[18] Kavitha K V, Deshpande SR, Pandit AP, Unnikrishnan A. Application of tele-podiatry in diabetic foot management: A series of illustrative cases. Diabetes Metab Syndr Clin Res Rev 2020. https://doi.org/https://doi.org/10.1016/j.dsx. 2020.10.009.

[19] Orlando JF, Beard M, Kumar S. Systematic review of patient and caregivers' satisfaction with telehealth videoconferencing as a mode of service delivery in managing patients' health 2019:1-20.

https://doi.org/https://doi.org/10.1371/jour nal.pone.0221848.

[20] Tchero H, Noubou L, Becsangele B, Mukisimukaza M, Retali G, Rusch E. Telemedicine in Diabetic Foot Care: A Systematic Literature Review of Interventions and Meta-analysis of Controlled Trials 2017;16:274-83. https://doi.org/10.1177/1534734617739195.

[21] Ohannessian R. Telemedicine: Potential applications in epidemic situations. Eur Res Telemed 2015:95-8.

[22] Su D, Zhou J, Kelley MS, Michaud TL, Siahpush M, Kim J, et al. Does telemedicine improve treatment outcomes for diabetes? A meta- analysis of results from 55 randomized controlled trials. Diabetes Res Clin Pract 2016:136-48.

https://doi.org/10.1016/j.diabres.2016.04.01 9.

[23] Garg SK, Rodbard D, Hirsch IB, Forlenza GP. Managing New-Onset Type 1 Diabetes During the COVID-19 Pandemic: Challenges and Opportunities. DIABETES Technol Ther 2020;22:431-9. https://doi.org/10.1089/dia.2020.0161.

[24] Bates M, Edmonds M, Kavarthapu V, Manu C, Rashid H, Vas P. Diabetes Foot Care in the COVID-19 Pandemic. King's Coll Hosp 2020:14.

[25] Rogers LC, Lavery LA, Joseph WS, Armstrong DG. All Feet On Deck-The Role of Podiatry During the COVID-19 Pandemic: Preventing hospitalizations in an overburdened healthcare system, reducing amputation and death in people with diabetes. J Am Podiatr Med Assoc 2020:1-11.

https://doi.org/https://doi.org/10.7547/20051.

[26] Adiputra PAT. Dampak Pandemi COVID-19 pada Pelayanan Pasien Kanker di Rumah Sakit Tersier di Indonesia: Serial Kasus. JBN (Jurnal Bedah Nasional) 2020. https://doi.org/10.24843/jbn.2020.v04.is01.p 07.

[27] Velavan TP, Meyer CG. The COVID-19 epidemic. Trop Med Int Heal 2020;25:278-80. https://doi.org/10.1111/tmi.13383.

[28] Hinchliffe RJ, Brownrigg JRW, Andros G, Apelqvist J, Boyko EJ, Fitridge R, et al. Effectiveness of revascularization of the ulcerated foot in patients with diabetes and peripheral artery disease : a systematic review. Diabetes Metab Res Rev 2016;32:136-44. https://doi.org/10.1002/dmrr.2705. 